\title{
NIEMCY CZY ŻYDZI? WROCŁAWSKIE ŚRODOWISKO EDYTY STEIN
}

Mówiąc o wrocławskim środowisku Edyty Stein, należałoby wyodrębnić dwie sfery: prywatną i publiczną. Do pierwszej bez wątpienia należał dom rodzinny, a do drugiej: szkoły i uniwersytet, jako środowisko rówieśnicze, oraz gmina żydowska. W skali makro, obok trzech ostatnich, można również rozpatrywać miasto - Breslau - oraz Prusy czy Niemcy sprzed i w okresie Republiki Weimarskiej, choć wówczas Edyta przebywała w rodzinnym mieście jedynie gościnnie. Odnośnie do kraju - koniecznie należy wskazać cały szereg procesów społecznych, jakie miały miejsce w Niemczech w XIX wieku: industrializację, pociągającą za sobą wzrost demograficzny, zwłaszcza w dużych miastach, a w kontekście żydowskim procesy emancypacji, akulturacji i integracji, szczególnie po zjednoczeniu Niemiec (1871 rok), ale także zjawiska antysemityzmu oraz syjonizmu (u schyłku wieku XIX). Skoncentruję się tu jednak jedynie na mieście, w którym urodziła się i wychowała Edyta Stein.

\section{Skala makro}

Breslau był jednym z większych miast niemieckich, ale w pewnym sensie uznawano je za peryferyjne ze względu na bliskość granicy. Mieszkali w nim przede wszystkim Niemcy, w mniejszości także Polacy i Żydzi - ci ostatni to ok. 4\% ówczesnej populacji. Większość dominującą 
stanowili chrześcijanie, głównie protestanci, a katolicy byli w mniejszości ${ }^{1}$. Można więc mówić o ówczesnym Wrocławiu jako o miejscu styku różnych religii, wyznań oraz kultur². Uwzględnić też należy panujący wówczas kult cesarza, gloryfikację Rzeszy Niemieckiej oraz pruski patriotyzm, jaki niewątpliwie kształtowano. W takiej atmosferze wzrastała panna Stein. W jej pismach: listach ${ }^{3}$ i Dziejach pewnej rodziny żydowskiej ${ }^{4}$ odczytać można sporo tekstów poświadczających utożsamianie się z krajem i kulturą niemiecką. Chronologicznie pierwszym tekstem, który zacytuję, jest życiorys umieszczony w jej pracy doktorskiej (druk z roku 1917): „Ja, Edith Stein, córka zmarłego kupca Siegfrieda Stein i jego żony Auguste, z domu Courant, urodziłam się we Wrocławiu 12 października 1891 roku. Jestem obywatelską pruską i Żydówką"5. Notabene, podobnie zaczynały się inne życiorysy w publikowanych doktoratach ${ }^{6}$. Retrospektywnie wróciła Edyta też do poczucia własnej tożsamości, opisując czas studiów w Getyndze: „uświadomiłam sobie istotę pruskości i umocniłam się w moim prusycyzmie"7. O wrocławskim okresie studiów napisała: „Wszystkie drobne przywileje, które nam zapewniała studencka legitymacja - tańsze bilety do teatru i na koncer-

${ }^{1}$ Analizę stosunków międzyreligijnych i międzywyznaniowych przeprowadziła i opisała A. Powęska-Wolff w: A bliźniego swego... Kościoły w Niemczech wobec "problemu żydowskiego", Poznań 2003.

2 Podstawowe opracowania dotyczące historii żydowskich mieszkańców Breslau to prace: L. Ziątkowskiego: Dzieje Żydów we Wrocławiu, Wrocław 2000; oraz Rozwój liczebny ludności żydowskiej we Wrocławiu w latach 1742-1914, "Sobótka” 1991, nr 2(46), s. 169-189. Zob. też: T. van Rahden, Juden und andere Breslauer. Die Beziehung zwischen Juden, Protestanten und Katholiken in einer deutschen Großstadt von 1860 - bis 1925, Göttingen 2000. Popularnonaukowy charakter mają pionierskie publikacje M. Łagiewskiego, Wrocławscy Żydzi 1850-1944, Wrocław 1997 i 2010; zob. także przedmowę tegoż w: A. Ascher, Oblężona społeczność. Wrocławscy Żydzi w czasach nazizmu, tłum. J. Tyszkiewicz, Wrocław 2009, s. 7-13.

${ }^{3}$ E. Stein, Autoportret $z$ listów, cz. 1: 1916-1933, tłum. J.I. Adamska OCD, A. Talarek, Kraków 2002; taż, Autoportret $z$ listów, cz. 2: 1933-1942, tłum. J.I. Adamska OCD, A. Talarek, Kraków 2003.

${ }^{4}$ E. Stein, Dzieje pewnej rodziny żydowskiej oraz inne zapiski autobiograficzne, tłum. J.I. Adamska OCD, Kraków 2005.

${ }^{5}$ Zum Problem der Einfühlung (Teil II/IV der unter dem Titel "Das Einfühlungsproblem in seiner historischen Entwicklung und in phänomenologischer Betrachtung" eingereichten Abhandlung.) Inaugural-Dissertation zur Erlangung der Doktorwurde der Hohen Philosophischen Fakultät der Großherzoglich Badischen Albert-Ludwigs-Universität zu Freiburg i. Br. vorgelegt und mit ihrer Genehmigung veröffentlicht von Edith Stein aus Breslau, Halle, Buchdruckerei des Waisenhauses 1917. Przekład cytatu własny.

${ }^{6}$ Hermann Badt (późniejszy ministerialny dyrektor do spraw wewnętrznych, jak podaje Łagiewski: Wroctawscy Żydzi, dz. cyt., s. 10), napisał: „Ich bin Jude, preussischer Staatsangehörigkeit" (H. Badt, Die rechtliche Natur des Grundsatze über materielle Rechtskraft der Zivilurteile, Breslau 1909). Jego siostra natomiast: „Bertha Badt - Jüdischer Religion” (B. Badt, Annette von Droste-Hülshoff in ihren Beziehungen zur englischen Literatur, Leipzig 1908).

7 E. Stein, Dzieje pewnej rodziny żydowskiej, dz. cyt., s. 341- 342. 
ty, itd. - uważałam za pełną miłości troskę państwa nad swymi wyróżnionymi dziećmi; budziło to we mnie pragnienie odwdzięczenia się później narodowi i państwu przez moją pracę zawodową"8. Równocześnie (choć chronologicznie nieco wcześniej) krytycznie odnosiła się do swego wrocławskiego środowiska: „Marzyłam o szczęściu i sławie. Byłam przekonana, że jestem przeznaczona do czegoś wielkiego i zupełnie nie mieszczę się $\mathrm{w}$ ciasnych, mieszczańskich ramach, w jakich się urodziłam"9. Podkreślone w pierwszym cytacie obywatelstwo i przynależność religijna raczej, a nie narodowa, wskazują na złożoną tożsamość, którą deklaruje Edyta. Jest Niemką, obywatelką Prus, ale i Żydówką. Z dystansem też podchodzi do swojego mieszczańskiego środowiska, choć nie może wyjść poza jego nawias. Zatem tytułowe pytanie: „Niemcy czy Żydzi?” zastąpić należałoby więc konstatacją: „Niemcy i Żydzi”.

Inną kwestią jest adekwatność określenia „Żydówka”. Wiemy, że Edyta uważała siebie wówczas za agnostyczkę, osobę poszukującą, na pewno niewierzącą, ale czy niepraktykującą ${ }^{10}$ ? Faktycznie niezwiązana była ani z gminą żydowską, ani z żadnym wyznaniem chrześcijańskim. Napisała jednak o sobie, że od trzynastego roku życia nigdy nie złamała postu w Dzień Pojednania (Jom Kipur)! Mimo to termin „Żydówka” wskazywałby na pochodzenie nie tyle religijne, co etniczne i społeczno-kulturowe. Niewątpliwie warto by, może przy innej okazji, przeanalizować, jak ewoluowało u Edyty Stein rozumienie pojęcia "Żydówka”. Jej powyższa autodeklaracja nie miała jednak znaczenia w kontekście prawa żydowskiego i późniejszych ustaw norymberskich. Panna Stein pozostała Żydówką. W swoim testamencie pisała zresztą o narodzie żydowskim ${ }^{11}$. Jacy zatem byli Żydzi w jej współczesnym Breslau?

\section{Gmina żydowska - synagoga}

W XIX i XX wieku Wrocławska Gmina Żydowska była jedną z większych w Niemczech. Wiek XIX znamionowały procesy reformy religijnej, a ich areną - za sprawą rabina Abraham Geigera - stał się również

\footnotetext{
8 Tamże, s. 235.

9 Tamże, s. 91. Por. krytykę podwójnej moralności praktykowanej przez żydowską burżuazję: tamże, s. 80 .

10 Tamże, s. 85.

11 Tamże, s. 577. Tekst testamentu z 1939 r. dołączony do wydania Dziejów..., dz. cyt., s. 576-578. W liście z 1941 r. Stein pisała o "Niemcach niearyjskiego pochodzenia” (E. Stein, Autoportret..., cz. 2, dz. cyt., s. 747). Problem rozumienia i definiowania pojęć „naród” i „narodowość" przekracza ramy tego artykułu.
} 
Wrocław. Za konsekwencję tych przemian uznać należy między innymi prawny podział gminy żydowskiej w 1854 roku na dwie frakcje: ortodoksyjną i liberalną, zwaną też reformowaną. Do tej ostatniej frakcji - i to trzeba podkreślić - należała rodzina Stein po osiedleniu we Wrocławiu. Augusta Stein chodziła do Nowej, tak zwanej Wielkiej Synagogi (Am Anger 8, dziś ul. Łąkowa $)^{12}$. Oznakami reformy były między innymi używane $w$ niej organy, modlitwy w języku hebrajskim przeplatane śpiewami hymnów po niemiecku, kazania głoszone $\mathrm{w}$ języku krajowym przez wykształconych na uniwersytetach rabinów. Równocześnie pobierali oni naukę, a niejednokrotnie i wykładali potem w drugiej kuźni rabinackich talentów, którą było Żydowskie Seminarium Teologiczne (ŻTS) we Wrocławiu. Studiowali w nim i pracowali rabini13: Jakob Guttmann (1845-1919, był on również przewodniczącym Związku Rabinów w Niemczech), Marcus Brann (1849-1920), Aron Heppner (-1938) i inni. W rodzinie Stein i Batzdorff14 żywa jest pamięć o rabinie Hermanie Vogelsteinie (1870-1938). Siostrzenica Edith - Erika Tworoger była słuchaczką ŻST przed emigracją do Palestyny. Zarówno ona, jak i Augusta chodziły do znajdującej się tam (Wallstrasse, dziś ul. Włodkowica) sali modlitw. To właśnie w niej miało miejsce nabożeństwo, w którym Edyta uczestniczyła wraz z matką i które wspomina następująco: „Ostatnim dniem mego pobytu w domu był 12 października, moje urodziny. Była to zarazem uroczystość żydowska, zakończenie święta Kuczek [Szawuot, czyli Święto Namiotów - przyp. A.R.]. Moja matka udała się na nabożeństwo do synagogi przy szkole rabinackiej. Poszłam z nią, bo dzień ten chciałyśmy przeżyć jak najbliżej siebie"15.

Gmina to jednak nie tylko rabini, ale przede wszystkim jej członkowie. Nie sposób tu analizować religijności wrocławskich Żydów. Mówiąc o gmi-

12 Jej opis zawiera list Susanne Biberstein z 29 września 1935 r. wysłany do Edyty (znajdującej się już wówczas w Karmelu). Zob. tamże, s. 221-222.

13 Inne ważne postacie wrocławskiej gminy żydowskiej i ŻST, jeszcze przed przybyciem Steinów do Wrocławia, to: Heinrich Graetz, Manuel Joel, Jakob Caro i inni. Notabene, panny Stein znały synów wrocławskich rabinów (ortodoksyjnego) Rosenthala - Felixa, syna Ferdinanda, i (reformowanego) Guttmanna - Juliusa, syna Jacoba. Por. E. Stein, Dzieje pewnej rodziny żydowskiej, dz. cyt., s. 280 i 505. Z moich własnych badań potwierdzam, że Stein znała także córkę nieżyjącego już wówczas nauczyciela, rabina Benno Badta.

${ }^{14} \mathrm{~S}$. Batzdorff, Edith Stein - meine Tante. Das jüdische Erbe einer katholischen Heiligen, Würzburg 2000; polskie wydanie: Ciocia Edyta. Żydowskie dziedzictwo katolickiej świętej, tłum. M. Grzywacz, Poznań 2011, s. 54. W Archiwum Żydowskiego Instytutu Historycznego odnalazłam też dokument z 1919 roku. Informuje on, iż Ernie Stein i Hansowi Biberstein ślubu udzielał właśnie rabin Herrmann Vogelstein; zob. Archiwum ŻIH, Gmina Wrocław, sygn. 105/210, s. 87.

${ }^{15}$ E. Stein, Dzieje pewnej rodziny żydowskiej, dz. cyt., s. 556. Faktycznie cytat ten pochodzi z tekstu Jak wstapitam do Karmelu w Kolonii. Przyczynek do kroniki Karmelu w Kolonii. 
nie, zwrócę uwagę na obecność w niej osób religijnych, pobożnych, troszczących się o podtrzymywanie żydowskiej religijnej tożsamości. Równocześnie utożsamiali się oni z kulturą niemiecką i krajem, będąc lojalnymi obywatelami. We Wrocławiu żyło i aktywnie działało na rzecz miasta sporo osób mających żydowskie korzenie, a nie należących do gminy, osób, dla których religia żydowska nie miała znaczenia (np. rodzina Asch) ${ }^{16}$. W mieście przebywali również tak zwani Ostjuden - Żydzi Wschodni. W XIX wieku często skupieni byli w prywatnych czy terytorialnych synagogach (np. lwowskiej, wołyńskiej, Sklowera' ${ }^{17}$ ) oraz należącej wpierw do Żydów reformowanych, a potem (od 1872 roku) do ortodoksów i zachowanej do dziś Synagogi Pod Białym Bocianem ${ }^{18}$. Z bożnic terytorialnych do Nocy Kryształowej funkcjonowały: bożnice Sklowera, Synagoga Krajowa i Synagoga Lwowska19. Sporą i swoistą grupę stanowili Żydzi pochodzący z Poznańskiego - wielu spośród nich było rabinami, osobami pobożnymi, związanymi z gminą i kulturą żydowską ${ }^{20}$. Uogólniając, z czasem następował jednak również proces akulturacji, integrowania się z środowiskiem chrześcijańskim, odchodzenia od przestrzegania nakazów prawa religijnego, tradycji ojców, religii, a w życiu społeczno-politycznym coraz chętniej sprzyjano ideom liberalnym ${ }^{21}$.

W swych pismach Edyta niewiele uwagi poświęca gminie żydowskiej. Opisując rytualny ślub Erny, nie wymienia imiennie obecnego w domu na tej uroczystości rabina ${ }^{22}$. O synagodze czytamy najczęściej w opisach pobożności jej matki²3. Stein wspomina też, choć już $\mathrm{w}$ handlowych okolicznościach, polskich Żydów pośredniczących w handlu drewnem w firmie jej matki²4. Oni należeć mogli do ortodoksyjnej części gminy.

16 Por. losy rodzin Bauer i Asch, także przez analogię i L. Morgenstern, w: D. Nick, Jüdisches Wirken in Breslau. Eingeholte Erinnerung - der Alte Asch und die Bauers, Würzburg 1998 Polskie tłumaczenie, Dzieło Żydów Wroctawia: stary Asch i Bauerowie - pamięć ocalona, tłum. A.K. Haas, Wrocław 2005.

17 Synagoga Sklowera skupiała Żydów litewskich, białoruskich, podlaskich. Zob. L. Ziątkowski, Dzieje Żydów..., dz. cyt., s. 72.

18 Synagoga przy ul. Włodkowica 5. Nieustannie, acz błędnie, utożsamia się ją z synagogą Augusty Stein. Susanne Batzdorff poświadcza (i wielokrotnie to podkreślała!), że Augusta miała swoje stałe miejsce na balkonie Nowej Synagogi (Am Anger 8). Zob. S. Batzdorff, Ciocia Edyta, dz. cyt., s. 54.

${ }^{19}$ L. Ziątkowski, Dzieje Żydów..., dz. cyt., s. 23.

20 Tamże, s. 50. L. Ziątkowski podaje, że w 1919 roku tylko 7,2 procent Żydów pochodziło ze wschodu. Tamże, s. 51.

${ }^{21} \mathrm{~Np}$. brat Edith - Arno Stein; zob. E. Stein, Dzieje pewnej rodziny żydowskiej, dz. cyt., s. 205-206. Liberalną „Breslauer Zeitung” "czytywano niemal w każdej żydowskiej rodzinie” (tamże, s. 264).

${ }^{22}$ Tamże, s. 297-299.

23 Tamże, s. 84-85.

24 Tamże, s. 48. 
Okres młodości Edyty Stein przypada na tak zwany renesans żydowski, czyli silny prąd w judaizmie niemieckim (zwłaszcza berlińskim), który charakteryzowały powroty do żydowskich korzeni, odnowa i pogłębianie wiedzy religijnej i wiary ${ }^{25}$. Wynikał on z poczucia rozczarowania niemieckich Żydów fiaskiem idei integracji, koniecznością przedefiniowania swojej tożsamości narodowej, a zwłaszcza religijnej.

Podsumowując, żydowskie środowisko nie było jednorodne. Gminę tworzyli ludzi przestrzegający (w różnym stopniu) nakazów prawa religijnego, zachowujący lub odchodzący od tradycji, a nawet tożsamości żydowskiej, czego przykładem jest również rodzina Stein. Wspominając dzieciństwo, Edyta pisze przede wszystkim o rodzinie żydowskiej, spotkaniach i zabawach $\mathrm{z}$ kuzynami i kuzynkami $\mathrm{w}$ gronie rodzinnym lub przed synagogą w sobotni poranek. Opisuje jedynie domowe praktyki religijne. Wrocławska Gmina Żydowska jako taka w ogóle nie jest obecna w jej wspomnieniach. Co miało na to wpływ? Czy tylko jej odejście od religii ojców? Sądzę, że przesądziła o tym przede wszystkim silna akulturacja czy wręcz asymilacja niemieckich Żydów. Postawy te kształtował zapewne dom rodzinny, przed wszystkim jednak edukacja w szkołach nieżydowskich.

\section{Szkoła, uniwersytet, środowisko rówieśnicze}

Edyta, podobnie jak jej siostry (i matka) uczęszczała do szkoły miejskiej, a więc i wyznaniowej. Panny Stein chodziły do protestanckiej szkoły im. Wiktorii ${ }^{26}$. W kontekście wyznania wspominała ona swoje koleżanki; były wśród nich chrześcijanki i Żydówki27, Niemki i Polki²8. Edyta podkreśliła: „oprócz Juliii29 i mnie było jeszcze w naszej klasie sześć Żydówek, ale żadna nie otrzymała prawdziwie religijnego wychowania. [...] Nie

$25 \mathrm{Z}$ renesansem żydowskim należy wiązać nazwiska tak znanych postaci, jak Martin Buber, Gershom Scholem, Franz Rosenzweig, a także mniej znanej wrocławianki, później berlinianki, Berthy Badt-Strauss.

26 Podobnie jak ich kuzynki, Adelheid i Martha Courant (tamże, 221-222). Augusta chodziła w Lublińcu do szkoły katolickiej (tamże, s. 29).

27 Z mieszanego małżeństwa (matka Polka) była Mariechen (tamże, s. 176-77). Kaethe Kleemann - jej rodzice to ubodzy Żydzi z Lublińca (tamże, s. 177-178). Inne wspominane koleżanki to Hanna Tworoger i Lotte Henschel, prawdopodobnie też Żydówki (tamże. s. 198).

${ }^{28}$ Edyta udzielała korepetycji Lenie - Polce o „komicznej niemczyźnie” (tamże, s. 259).

29 Julia Heimann pochodziła z żydowskiej rodziny zamożnych bankierów. Edyta wspominana ją kilkakrotnie, między innymi przy okazji zdawania egzaminu maturalnego (tamże, s. $194-195,200,216-217)$. 
zauważyłam zresztą u dziewcząt większej pobożności ${ }^{30}$. [...] Tylko jedna dziewczyna w mojej klasie była katoliczką"31 - to późniejsza benedyktynka Augustyna (Margarete) Glatzel - „dopóki szkoła mieściła się przy Ritterplatz [pl. Nankiera - przyp. A.R.], do szkoły i ze szkoły szłyśmy razem [...]. Nigdy nie poruszałyśmy tematów religijnych"32.

Najmłodsza z sióstr Stein nie chodziła na lekcje religii ani w szkołach, ani w gminie, nie miała też lekcji prywatnych (i starsze zapewne też nie). Nie można zatem mówić o jej religijnej (żydowskiej) zinstytucjonalizowanej edukacji33. Religia chrześcijańska natomiast była jej zupełnie obca. Najprawdopodobniej postrzegała jednak przestrzeń w kategoriach Żydów i gojów, o czym świadczy zapisane później zdanie o zabarwieniu ewidentnie pejoratywnym: „było to dla żydowskiej wrażliwości wprost brakiem serca, właściwym - jak myśleliśmy - gojom" 34 .

Do szkoły im. Wiktorii Edyta wróciła w 1916 już jako nauczycielka ${ }^{35}$. Było to możliwe między innymi dzięki jej studiom uniwersyteckim. Pierwsi profesorowie, jakich wspomina Edyta, to William Stern i Richard Hönigswald; mieli oni żydowskiej pochodzenie, co utrudniało im karierę akademicką ${ }^{36}$. U pierwszego $\mathrm{z}$ nich uczestniczyła w seminarium psychologicznym, a zwłaszcza w spotkaniach Grupy Pedagogicznej, niezwykle znaczącej dla niej grupy rówieśniczej: „Weszłam w krąg młodych ludzi, którym zawdzięczam na pewno to, co było najbardziej wartościowe w okresie moich studiów we Wrocławiu. Zwali się oni Grupą Pedagogiczną i składali się głównie z uczniów i uczennic seminarium Sterna" 37 . Szkolna koleżanka, Lene Kopel, wprowadziła później Edytę „w krąg literacki panny Freyhan,

\footnotetext{
30 Wspomina jednak, że na komers maturalny zamówiono potrawy z "restauracji rytualnej” dla „dawnego nauczyciela religii” (tamże, s. 218).

31 Tamże, s. 195.

32 Tamże.

${ }^{33}$ Biorąc po uwagę wzór matki i babek, z pewnością religijne wzorce czerpała z domu.

34 Tamże, s. 132.

35 Zastępowała chorego nauczyciela, ucząc niemieckiego, łaciny, historii i geografii. Wcześniej jej starsza siostra Elza - jako Żydówka - nie mogła otrzymać pracy w szkole i musiała szukać zatrudnienia poza miastem, między innymi w Hamburgu (tamże, s. 106, 495 i n., 499, 503).

36 Tamże, s. 227-228. O Sternie napisała, że „reprezentował pewien określony typ żydowski [...], między innymi średni wzrost, pochylony, blada twarz, brunatna broda, oczy patrzyły mądrze i dobrotliwie [...], wyglądał jak Natan Mędrzec" (tamże, s. 244-245). O innych profesorach żydowskiego pochodzenia, Hamburgerze i Tarnowskim, zob. tamże, s. 257. Por. też: M. Łagiewski, Wrocławscy Żydzi, s. 9, 154-161. Natomiast w Getyndze żydowskie korzenie mieli, np. profesorowie Edmund Husserl, Adolf Reinach i Max Scheller.

37 E. Stein, Dzieje pewnej rodziny żydowskiej, dz. cyt., s. 237. W tym czasie Edyta stała się także aktywną działaczką kilku stowarzyszeń studenckich (nieżydowskich!): Związku Studentek, Pruskiego Związku dla Prawa Głosu Kobiet, Związku ds. Reformy Szkolnictwa.
} 
w którym brały udział Rose Guttmann i Lilli Platau"38. One również należały do Grupy Pedagogicznej. Edyta zaprzyjaźniła się także z Kaethe Scholz protestantką pochodzącą z ówczesnej podwrocławskiej wsi Brochów: „różnica wyznań i pochodzenia nie mąciły naszej przyjaźni i tematy religijne omawiałyśmy z taką samą szczerością, jak wszystkie inne, które nas poruszały"39. Jej szukanie prawdy, studia filozoficzne oraz szerszy i zróżnicowany pod względem religijnym krąg znajomych na uniwersytecie, zwłaszcza później w Getyndze, zaowocowały refleksją i poznaniem myśli chrześcijańskiej $^{40}$.

Grupa rówieśnicza poszerzyła się w sposób naturalny w szkole, a jeszcze szersze kręgi zatoczyła na uniwersytetach. Podkreślić muszę jednak, że wśród studentów i studentek sporą część stanowiły osoby o żydowskim pochodzeniu. Charakteryzując swoich znajomych, Edyta zwracała uwagę na ich pochodzenie, zwłaszcza ze Śląska lub Wschodu. Paula Berga opisała pozytywnie, odwołując się jednak do negatywnego stereotypu: „nie miał też w żadnym wypadku nieprzyjemnego tonu nieokrzesanego Żyda ze wschodu, który niemieckich «zasymilowanych Żydów» denerwował jeszcze bardziej aniżeli aryjczyków". Paul mówił czystym i starannym niemieckim ${ }^{41}$. Podobnie o Georgu Moskiewiczu napisała, że był to wszechstronnie wykształcony człowiek i ,jak wielu Żydów wschodnich, miał rude włosy i jasne oczy. Po jego bladej, nerwowej twarzy i trochę wystraszonym, niespokojnym spojrzeniu można się było domyśleć, że mu wewnętrznie coś doskwiera. Ile tragizmu kryło jego życie, dowiedziałam się dopiero później”"42. Pisząc o Grete Henschel, użyła sformułowania: „ona była typową Żydówką: ciemnowłosa, silna, głośna i żywa, tryskająca humorem i cięta" 43 . Powyższe osoby opisuje więc Stein, koncentrując się na ich wyglądzie i zachowaniu stereotypowo - i pejoratywnie - kojarzonym z żydowskim.

Oprócz Paula Berga, pozytywnie i nawiązując też do przepisów talmudycznych, wspominała Edyta innego studenta, Eduarda Metisa. Scharakte-

38 Tamże, s. 198. Niestety, nic więcej nie mogę powiedzieć o tej grupie.

${ }^{39}$ Tamże, s. 233.

${ }^{40}$ W Getyndze chodziła niekiedy do kościoła protestanckiego (tamże, s. 409, 513). Religijność Reinachów uznać można za znaczące świadectwo z grona jej najbliższych, podobnie jak docenioną później - pobożność Augusty Stein. Na jej drodze stanęli wybitni teolodzy - protestanci Johannes Hering i Rudolf Bultmann oraz katolicy Dietrich von Hildebrand, Raissa i Jacques Maritain. O naukowym środowisku Edyty pisałam na stronie Domu Edyty Stein: www.edytastein.org.pl/pl/4-edyta-stein/2-biografia/ [dostep 10.11.2013]

${ }^{41}$ E. Stein, Dzieje pewnej rodziny żydowskiej, dz. cyt., s. 153-154. Wspomina też, że jej kuzyn Richard Courant znał żargon żydowski (tamże, s. 480). Żargon, a więc zapewne jidysz.

42 Tamże, s. 249.

43 Tamże, s. 504. 
ryzowała go jako człowieka bardzo czystego ${ }^{44}$ : „Od innych moich towarzyszy tym się odróżniał, że był wierzący i dokładnie przestrzegał przepisów Prawa. Nie mówiliśmy o tym wiele. [...] W moim domu przyjmował tylko owoce. [...] Nie przekroczyłem [powiedział Metis - przyp. A.R.] żadnego zakazu"45. Religijność większości osób z jej grona oraz rodzin koleżanek kształtowała się bowiem odmiennie. Najbliższy krąg Edyty stanowili przyjaciele Erny i jej: Rose Guttmann i Lilli Platau oraz Hans Biberstein. Edyta Stein napisała o nich, że „u Guttmannów, Bibersteinów i Platau sprawę wyznania traktowano nawet liberalniej niż $u$ nas, odchodząc zupełnie od wszelkich zwyczajów rytualnych"46. Warto zwrócić uwagę na powszechność tych postaw. Jak wyglądała ona zatem w rodzinie Stein?

\section{Skala mikro}

\section{Rodzina i dom}

Zasadniczo cytowane tu pisma Edyty Stein i jej siostrzenicy Susanne Batzdorff stanowią najlepsze źródła wiedzy o ich domu rodzinnym. Są one od lat publikowane, analizowane i cytowane. $Z$ tego względu przypomnę je jedynie pokrótce i syntetycznie. Warto zwrócić uwagę, iż pośród znajomych Edyty byli Żydzi (liberalni, ortodoksyjni, ze Wschodu, konwertyci), katolicy i protestanci oraz niewierzący w Boga. Tak też opisać można członków jej bliższej i dalszej rodziny.

O matce Edyta pisała: „jako prawdziwa Żydówka nade wszystko pragnęła dobrze wydać córki za mąż" $47^{\prime \prime}$. Sprecyzowała też, na czym polegała "żydowskość" jej przodków: „Jednakże codzienne studium Pisma Świętego i Talmudu, [...] jeszcze dziś praktykowane przez Żydów ze Wschodu, nie było $\mathrm{w}$ zwyczaju w rodzinie moich dziadków, mimo że przepisów Prawa przestrzegano jak najwierniej" ${ }^{48}$. Podkreślała jednak, że matka przestrzegała takich zwyczajów, jak: darowanie pierwocin, nadawanie dzieciom imion po

44 Tamże, s. 264.

45 Tamże, s. 265-266.

${ }^{46}$ Hans mieszkał wówczas z matką, Dorotheą Biberstein, z domu Ledermann (1855-1934). Tamże, s. 153 i 142.

47 Tamże, s. 297. Augusta sprzeciwiła się mieszanemu narzeczeństwu Elzy, stąd jego fiasko (tamże, s. 70). Nie miała już jednak wpływu na ateistyczny styl życia po zamążpójściu za Maxa Gordona (tamże, s. 108, 113). Za to Erna (i zapewne Frieda) miały „rytualny ślub” (tamże, s. 297-299). Mieszane małżeństwo zawarł ich kuzyn Walter Courant; zob. też opis wzruszającej sceny z pogrzebu: tamże, s. 224-225.

${ }^{48}$ Tamże, s. 30. 
zmarłych przodkach, np. Adelheid po babci ${ }^{49}$. Augusta skupiała też rodzinę w piątkowe wieczory i w święta żydowskie, choć jej dzieci nie traktowały religii już tak poważnie jak ona ${ }^{50}$. W domu przygotowywano się do świąt, spożywano macę, chały, koszerne potrawy, a w Dzień Pojednania poszczono ${ }^{51}$. Trzeba zwrócić też uwagę na dobroczynność Augusty oraz zaangażowanie charytatywne Róży52.

Od religii ojców odeszły niektóre z dzieci Augusty53. Było to właściwie powszechne zjawisko od drugiej połowie XIX w. Kolejne pokolenia nie były tak gorliwe jak ich rodzice. Zmianę sytuacji przyniósł berliński „renesans”, a także okres Republiki Weimarskiej, a zwłaszcza nazizm. Na ten czas przypada młodość siostrzeńców Edyty ${ }^{54}$. Erika Tworoger to osoba bardzo religijna, „najgłębiej wierząca Żydówka w rodzinie” 55 . Jej wiara i troska o praktyki religijne były przyczyną napięć $\mathrm{w}$ domu Steinów, zwłaszcza w związku z prowadzeniem niewystarczająco koszernej kuchni przez Różę56. Być może konwersja Edyty wpłynęła na większą troskę o religijne wychowanie potomstwa Erny i Hansa: Ernsta Ludwiga i Susanne. Susse w jednym z pierwszych listów po emigracji do USA opisuje pierwszą Paschę57. Do dziś podtrzymuje ona pamięć o swej rodzinie, ciotce, pozostaje też wzorem dążenia do dialogu i integracji wielowyznaniowych, religijnych i nie, potomków Augusty Stein ${ }^{58}$.

\section{Wrocławscy Niemcy i Żydzi - mozaika religii i kultur}

W swoich pismach Edyta wielokrotnie podkreślała, iż posiada żydowskie korzenie. Trzeba jednak pamiętać, że Dzieje... spisywała retrospektywnie, w specyficznym i trudnym okresie, jakim są lata trzydzieste XX wieku. Wówczas, tak jak ona, wielu Żydów podejmowało wysiłek spisania własnej historii $\mathrm{w}$ celu udokumentowania i potwierdzenia swego niewątpliwego wkładu w kulturę niemiecką i europejską.

49 Tamże, s. 44.

50 Tamże, s. 53, 81 i n.

51 Tamże, s. 81-85, 394-395. Edyta twierdzła, że bracia przejawiali lekceważenie, odmawiając modlitwy (tamże, s. 83).

52 Tamże, s. 60. Por. Susanne Batzdorff, Ciocia Edyta, dz. cyt., s. 211-214.

${ }^{53} \mathrm{~Np}$. Elza, Rosa, Edit, a także wnukowie, np. Werner, Gerhard. Ateistkami były też Anni i Ilse.

${ }^{54}$ Również oni otrzymali drugie imiona po zmarłych dziadkach.

55 E. Stein, Dzieje pewnej rodziny żydowskiej, dz. cyt., s. 533.

${ }^{56}$ S. Batzdorff, Ciocia Edyta, dz. cyt., s. 215.

57 List z 4 kwietnia 1939 r.; E. Stein, Autoportret..., cz. 2, dz. cyt., s. 527.

58 Por. S. Batzdorff, Ciocia Edyta, dz. cyt., s. 60. 
Edyta Stein pisała jako Niemka, katoliczka o żydowskich korzeniach, aspirantka czy już karmelitanka. Dostrzec można w jej tekstach gloryfikowanie matki, a także tych elementów tradycji żydowskiej, które pomogły jej poznać Boga i stać się katoliczką. Wspominając znajomych, zwracała uwagę na ich pochodzenie, religię, strój, zachowanie, język, a więc na te elementy kulturowe, które można postrzegać $\mathrm{w}$ kategoriach swoje-obce. Kreują one poczucie tożsamości, inności, obcości lub swojskości. Edyta nie uniknęła stereotypów, zdecydowanie dystansując się wobec obecnych w jej wrocławskiej przestrzeni Żydów wschodnich - Ostjuden, a także Polaków. Odzwierciedlała w ten sposób obraz świata, jaki posiadali Niemcy i niemieccy Żydzi. Niewątpliwie był to świat złożony, pełen trudności i wyzwań, ale świat ich niemiecki i żydowski zarazem.

Fenomen Edyty Stein - osoby wykształconej, otwartej, postaci o złożonej tożsamości - nie byłby możliwy bez atmosfery jej rodzinnego domu i miasta: zróżnicowanych religijnie i tożsamościowo Żydów (liberalnych lub ortodoksyjnych), Niemców otwartych na innych lub nie..., atmosfery na pewno tworzącej rzeczywistość i przestrzeń wielokulturową.

\section{Jews or Germans? \\ The Breslau's Cultural Background of Edith Stein.}

\section{Summary}

This article is devoted to Edith Stein's background in Breslau. The basic sources are the texts of Edith Stein and Suzane Batzdorf, aided by the author's own research on the life of the Jewish Community in Wrocławin the 19th and 20th century. The main issue addressed in the paper regards the extent to which Edith Stein's life was influenced by the Jewish and German societies. Importantly, her education was not religious and her friends along with some family members were secularised. The identity of Breslau's Jews was complex; even though they were not multilingual, yet certainly multicultural, having been Jews and Germans at the same time. This variety was the keynote of Stein's background. The question therefore should not be formulated as'Jews or Germans?' but rather how much Jewish and how much German they were? The answer is as complicated as their complex identity. 